УДК 371.14+316.485

UDC 371.14+316.485

DOI: $10.31475 /$ ped.dys.2021.30.08

ОЛЕКСАНДРА МАРМАЗА,

кандидат педагогічних наук, проббесор (Украӥна, Харків, Харківський національний педагогічний університет ілені Г. С. Сковороди, вул. Алчевських, 29)

OLEKSANDRA MARMAZA,

Candidate of Pedagogical Sciences, Professor (Ukraine, Kharkiv, H. S. Skovoroda Kharkiv National Pedagogical University,

Alchevskykh St., 29)

ORCID: 0000-0002-0979-9256

\title{
Аксіологічний контент управлінських інновацій
}

\section{Axiological Content of Management Innovations}

У роботі зазначено, що особливість управлінської діяльності керівника закладу освіти на сучаснолу етапі визначається появою інноваційних технологій керівництва, а інновацій мають своє неповторне значення для кожного керівника, колективу, закладу в иілолу. Відповідно до поставленої мети (розкрити аксіологічні засади управлінських інновацій) обгрунтовано, шо управлінські інновацї доцільно розглядати у аксіологічнолу контенті - з точки зору їх иінності. За допомогою методів наукового пізнання розкрито аксіологічний контент інновацій в управлінні закладом освіти, який лає бути показником готовності та здатності керівника нетрадиційно вирішувати актуальні проблели й свідченнял високого професіоналізлу та інноваційної колпетентності. Констатовано, що аксіологічний підхід стає механізлол, шо забезпечує зв'язок між теорією $i$ практикою управління. На прикладі партисипативного управління та коучингу показано аксіологічний потенціал інновацій. Визначено критерії управлінських інновацій у аксіологічному контенті, підходи до оцінювання їх потенціалу.

Ключові слова: управління, інновацї, управлінські інновацї, інноваційний менеджлент, аксіологія інновацій, партисипативне управління, коучинг.

The paper notes that the peculiarity of the management activities of the head of the educational institution at the present stage is determined by the emergence of innovative leadership technologies, and innovations have their unique significance for each head, team, institution as a whole. In accordance with the set goal (to reveal the axiological principles of management innovations) it is substantiated that it is expedient to consider management innovations in axiological content - from the point of view of their value. It is determined that managerial innovations can relate to the content of activities, forms, methods, procedures, technologies and management techniques. The definition of innovative management of an educational institution is a specific purposeful activity that involves the application of new content, testing the effectiveness of creative management decisions, updated management principles, modernized functions, new technologies and techniques, optimized organizational structures, management systems or their components, methods and forms of activities.

Using the methods of scientific cognition, the axiological content of innovations in the management of an educational institution is revealed, which should be an indicator of readiness and ability of a head to unconventionally solve current problems and evidence of high professionalism and innovative competence. Determining the values of management innovations due to their importance is productive, as it allows in theoretical and practical aspects to consider the axiology of a particular innovation in terms of its relationship with the head, staff, features of the educational institution. The axiological potential of innovations is shown on the example of participatory management and coaching. Criteria of management innovations in axiological content and approaches to estimation are defined.

Keywords: management, innovations, management innovations, innovative management, axiology of innovations, participatory management, coaching.

Вступ/Introduction. Як зазначено у стратагемах розвитку освіти в Україні, управління освітою повинно здійснюватися на засадах інноваційних моделей відповідно до принципів сталого розвитку, грунтуватись на активному використані знань та наукових досягнень (Закон України «Про освіту», 2017; Концепція реалізації державної політики..., 2016; Стратегія сталого розвитку..., 2018). Основні шляхи реформування управління освітою - це наукове обтрунтування цілісної 
системи управління, впровадження інновацій в управління закладами освіти, які б відповідали вимогам часу.

З огляду на це, особливість управлінської діяльності керівника закладу освіти на сучасному етапі визначається раціоналізацією традиційних та появою інноваційних технологій керівництва.

Інновації е породженням розвитку високих технологій та насиченості ними матеріального й нематеріального буття людини. Інноваційність - це не тільки ознака сучасності, а передусім основа модернізації, запорука ефективності та якості.

Зауважимо, що інновації мають своє неповторне значення для кожного керівника, колективу, закладу в цілому. 3 огляду на це, управлінські інновації доцільно розглядати у аксіологічному контенті - з точки зору їх цінності.

Інноваційний менеджмент в освіті можна віднести до процесів, які швидко розвиваються, потребують активного впровадження в умовах сучасних змін, проте залишаються не досить дослідженими. Такий стан наукового знання та практики вимагае розв'язання низки суперечностей, насамперед: між вимогами до оновлення управління закладом освіти та незавершеністю розробляння теоретико-методологічного підгрунтя інноваційного менеджменту; між необхідністю впровадження інновацій та недостатнім усвідомленням керівників їх значення для ефективного управління.

Мета та завдання / Aim and Tasks. Мета: розкрити аксіологічні засади управлінських інновацій. Завдання: обтрунтувати актуальність управлінських інновацій на сучасному етапі реформування освіти; з'ясувати особливості інновацій (на прикладі партисипативного управління та коучингу) з точки зору їх цінностей для управління закладом освіти; визначити критерії оцінювання управлінських інновацій у аксіологічному контенті.

Методи / Methods. Для досягнення поставленої мети було використано комплекс теоретичних методів наукового пізнання: аналіз науково-методичної літератури, систематизація підходів до означеної проблеми, інтерпретація та уточнення понять, узагальнення результатів наукових пошуків.

Результати / Results. Розвиток закладу освіти неможливий без розвитку системи управління ним. Розвиток системи управління передбачає: збагачення усіх характеристик системи; оновлення функцій управління та конкретних управлінських дій; удосконалення організаційної структури управління; оптимізацію технологій та механізмів управління; особистісний розвиток керівників закладів освіти та підвищення їх професіоналізму.

У кожної системи управління є свій рівень актуального розвитку, тобто вже досягнутого і реалізованого потенціалу, та внутрішні передумови для збагачення цього потенціалу - зони найближчого розвитку. Проектування такої зони і найкращої траєкторії руху системи до їх верхніх границь - важлива задача під час управління розвитком системи управління (Мармаза О. I., 2017). Розвиток, як приріст потенціалу системи управління, означає не просте зростання ії̈ окремих можливостей, але й збільшення складності, різноманітності, неповторності, індивідуальності. Розвиток можливий за рахунок процесів оновлення, внесення в систему інновацій.

Н. Сас визначае поняття «інновації» як нововведення у галузі техніки, технології, організації праці та управління, заснованого на використанні досягнень науки і передового досвіду, а також використання цих нововведень у різних галузях і сферах діяльності (Сас Н., 2013).

Будь-яке управлінське нововведення має два аспекти: змістовий та організаційний. Змістовий пов'язаний із сутністю змін, які несе у собі нововведення. Організаційний аспект передбачає технологію, стадії, стани, методи засвоення нового. Нововведення мають свое призначення, конкретні функції та завдання. По відношенню до системи управління нововведення покликані сприяти підвищенню успішності, результативності, дієвості, якості та ефективності їі функціонування. По відношенню до керованого об’єкту та його результативності управлінські нововведення покликані сприяти створенню оптимальних стосунків «керівна - керована» система, тобто підвищенню коефіцієнту корисної дії індивідуальних та сумісних зусиль, усуненню перевантаження, підвищенню рівня мотиващії до роботи, створенню сприятливого мікроклімату та продуктивного стилю спілкування тощо. По відношенню до зовнішнього середовища управлінські інновації покликані сприяти підвищенню репутації закладу, його іміджу, якості раблік рілейшнз, вирішенню ділових проблем тощо.

Керівнику закладу освіти важливо усвідомити, що активна участь у реалізації управлінських нововведень є невід'емною частиною професійного та особистісного саморозвитку, гарним вміщенням інтелектуального капіталу.

За Н. Василенко, інноваційна діяльність керівників закладів освіти $е$ «процесом оптимального застосування ними традиційних і якісно нових управлінських функцій, операцій і дій, у результаті яких виникають нові управлінські ідеї, що змінюють результати управління; компетентність керівників з інноваційної діяльності є наявність у них додаткових знань і вмінь з педагогічної 
інноватики й менеджменту освітніх інновацій, досвіду і мотивації інноваційної діяльності, набуття особистісних якостей, які сприяють системному застосуванню педагогічних інновацій в управлінні» (Василенко Н., 2007).

Управлінські інновації можуть стосуватись змісту діяльності, форм, методів, процедур, технологій та технік управління.

Отже, інноваційне управління закладом освіти - це специфічна цілеспрямована діяльність, яка передбачае застосування нового змісту діяльності, перевірку ефективності креативних управлінських рішень, оновлених принципів управління, модернізованих функцій, нових технологій та технік, оптимізованих організаційних структур, управлінських систем або їх компонентів, методів та форм діяльності.

Мета інноваційного управління полягає в акумулюванні наукових, матеріально-технічних, людських, часових, освітніх ресурсів для підвищення ефективності управління закладом освіти.

До загальної характеристики інноваційного управління слід віднести те, що воно грунтуеться на теоретичних положеннях наукового менеджменту та інноватики. Водночас інноваційне управління має свою специфіку, яка зумовлена галуззю діяльності, у нашому випадку - освітньою.

Цілі і завдання системи управління закладом освіти регулюються відповідними законодавчонормативними та правовими документами. Інновації не повинні ставити їх під сумнів. Вони не можуть змінювати систему в цілому, а лише шляхи, методи, засоби досягнення цілей.

Зовнішні фактори, що впливають на провадження інновацій в управління, по-перше, криються у глобалізації, входженні країни у европейський простір, що вимагає узгодження стандартів та принципів діяльності. По-друге, пов'язані із щільним проникненням теорії та практики класичного менеджменту в управління закладами освіти. У цілому, застосування інноваційного управління в закладах освіти стимулюе до вирішення проблеми невідповідності управлінської діяльності складним трансформаційним процесам, пов'язаними із реформуванням усіх ланок системи освіти в Україні.

Інновації в управлінні закладом освіти також залежать від багатьох внутрішніх факторів, зокрема: особливості закладу, його традиції, репутація, кількість та якість учасників освітньої діяльності, замовлення на освітні послуги та їх якість, рівень акредитації, форма власності тощо.

Як правило, інновації стосуються не тільки керівника закладу освіти, а й педагогічний колектив, учнів, їх батьків. Такі інновації називають відкритими, наприклад: інноваційні методи організаційної роботи, регламентування праці та контролю, розподілу ресурсів чи винагород. За таких умов впровадження інновації повинно відбуватись за узгодженням та їх сприянням, набуває важливості формування корпоративної культури та культури ділового спілкування. У процесі впровадження управлінських нововведень необхідна ї інтеграція з розвитком персоналу, підвищення його компетентності, інноваційної культури в цілому.

Інновації в управлінні можуть бути реактивними (дозволяють адаптуватися до змін, які відбуваються в закладі освіти, та пом'якшити їх наслідки) та проактивними (мають превентивний характер, випереджають зміни, створюють умови для них).

$\mathrm{y}$ межах наукового підходу до управління виділяють інноваційні підходи, моделі та технології управлінської діяльності, а саме: персонологічне, програмно-цільове, адаптивне, партисипативне, кіберенетичне рефлексивне, фасилітативне управління; технології управління за результатами, коучингу; «паблік рілейшнз», фандрайзингу, технологія тайм-менеджменту тощо (Мармаза О., 2019).

В управлінні закладом освіти важливим е ціннісно-смисловий простір інновацій. У цьому контенті доцільно розглядати інноваційні підходи до управління, оскільки сліпе намагання відтворення технологій, які використовують у виробничій сфері, не завжди дає результати.

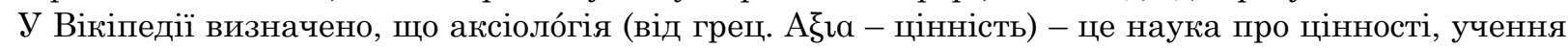
про природу духовних, моральних, естетичних та інших цінностей, їх зв'язок між собою, із соціальними, культурними чинниками та особистістю людини; розділ фрілософіï (Аксіологія, n.d.). У Енциклопедії сучасної України поняття аксіологія визначається як теорія цінностей, розділ філософіï, що з'ясовуе природу та різновиди цінностей, взаемовідношення між ними (досліджуе системи або множини взаємопов'язаних цінностей) (Лісовий В., 2001).

Отже, основним поняттям аксіології е «цінності». І. Підлісний зазначае, що «цінність - це те, ради чого робляться певні зусилля (щоб завоювати, утримати, зберегти), те, ради чого людина живе $\mathrm{i}$ діе, що заставляе їі удосконалюватися, що являе собою не лише належне, але і бажане» (Підлісний I., 2020).

Аксіологічний контент інновацій в управлінні закладом освіти має бути показником готовності та здатності керівника нетрадиційно вирішувати актуальні проблеми й свідченням високого професіоналізму та інноваційної компетентності. Аксіологічний підхід стає механізмом, що забезпечуе зв'язок між теорією і практикою управління. 
Так, технологія партисипативного управління сприятиме розвитку колегіальності, демократичності, що є важливим для сучасного етапу реформування управління в освітній галузі.

Термін партисипативне управління - «participative management» -дослівно означає «управління, засноване на участі». Ключовий термін «участь» передбачає різні форми участі працівників в управлінні організацією. Розрізняють три ступеня участі: висування пропозицій; вироблення альтернативи; вибір остаточного рішення. Концепція партисипативного управління виходить із положення, що якщо людина зацікавлено бере участь у різного роду діяльності організації, то вона тим самим отримуе від цього задоволення, працюе з більшою віддачею, краще, якісніше i продуктивніше (Мармаза О., 2019). Вважається, що по-перше, партисипативне управління, відкриваючи працівнику доступ до прийняття рішення з питань, пов'язаних з його діяльністю в організації, мотивуе до кращого виконання своеї роботи. По-друге, партисипативне управління не тільки сприяе тому, що робітник краще справляеться зі своєю роботою, але i призводить до більшої віддачі, більшого внеску окремого робітника в життя організації. Особливості діяльності сучасного керівника пов'язуються із демократичними способами організації стосунків в колективі, здатністю до оновлення власної діяльності, формуванням культури організації, що співпадае з основними ідеями партисипативної концепції.

Концепція партисипативного управління, яка заснована на розширенні повноважень та участі персоналу у прийнятті дієвих рішень з питань, важливих для діяльності організації і самих працівників, надае можливість педагогам розділити відповідальність, ризики і успіх разом 3 керівником.

Партисипативне управління заохочуе керівника діяти з позищії фасилітатора: він не змушуе та повчае педагогів, а мотивуе та спрямовуе колектив у необхідне творче русло. Такий підхід реалізуються через: знання особливостей колективу та педагогів; уміння організувати спільну роботу в колективі; залучення колективу до планово-прогностичної діяльності; лідерську позицію керівника в колективі та довіру до нього; уміння встановити партнерські стосунки, розвинути навички взаемодії, конструктивного спілкування, врегульовувати конфлікти; здатність до аналітичної діяльності, уміння застосовувати різні технології аналізу, робити відповідні узагальнення та висновки; чітке усвідомлення цілей та бажаних результатів діяльності колективу; збереження ентузіазму, почуття гумору, інтуїтивного відчуття, щирого ставлення до людей на усіх етапах сумісної діяльності; вміння ставити людей в ситуації необхідності самостійно прийняти рішення, визначитись із методами та змістом діяльності; вміння заохочувати та морально підтримувати навіть незначні успіхи персоналу. Така поведінка свідчить про прагнення керівника дійти згоди з усіма членами колективу (Мармаза О., 2019).

До основних переваг партисипативного управління, які мають соціально-психологічний характер, можна віднести такі: підвищуеться лояльність персоналу і його прихильність до організації; зміни впроваджуються менш болісно, співробітники краще розуміють сенс змін і підтримують їх; суперечності між керівниками і підлеглими не мають вираженого характеру; немає поділу на «ми» і «вони»; колектив сприймає себе командою і менше скаржиться на керівників; кожна людина може проявити себе і свої знання, висути пропозицію для рішення конкретної задачі; керівник стае координатором групового творчого процесу, забезпечуючи всебічне обговорення найбільш важливих проблем. Не меншим е й практичне значення від реалізації партисипативного управління: участь персоналу в управлінні підвищуе якість прийнятих рішень; розглядається більша кількість альтернатив, моделей; у обговорення та рішення привноситься більше практичного досвіду; з'являеться більше ідей, нових підходів, інновацій.

Однак партисипативний підхід має і свої обмеження та слабкі місця: обговорення часто займає багато часу, але на обговоренні все і закінчуеться; участь у різних групах не завжди викликає інтерес у рядових працівників; затягуеться прийняття рішень; з деяких питань підлеглі не мають достатньої компетентності для прийняття рішень, тому прийняті рішення можуть бути помилковими; робітники можуть свідомо блокувати невигідні їм рішення; діяльність керівника піддається контролю групи, що також може призвести до негативних наслідків через розпорошення відповідальності.

Проблема реалізації партисипативного управління зумовлюеться не тільки здатністю керівника бути фасилітатором, а й загальним рівнем культури організації. Відтак великого значення набувають процеси розвитку внутрішньошкільної культури.

Еволюція теорії та практики менеджменту свідчить про тенденцію психологізації управлінської діяльності, увагу до фактору «людина», розбудову суб’ект-суб’ектних стосунків, удосконалення особистого стилю діяльності керівника. У цьому контексті важливою інновацією $е$ коучинг.

Цілі коучингу в роботі з педагогічним колективом - це: розкриття внутрішнього потенціалу 
особистості кожного педагога; розвиток особистості через делегування відповідальності; усвідомлення високого рівня відповідальності кожним учасником спільної діяльності, а отже, у такий спосіб підвищення ефективності взаємодії та результатів діяльності.

Загальну основу коучингу можна описати декількома складовими: партнерство, розкриття потенціалу, результат. До основних ідей коучингу можна віднести такі: розвиток педагога як пріоритетний напрям в діяльності керівника з управління персоналом; розкриття потенціалу людини для максимального його використання; допомога педагогу розвивати компетенції й усунути обмеження для досягнення особистісно значущих та стійких змін у професійній та особистій сферах життя; допомога людині вчитися (керівник-коуч потрібен для того, щоб у співпраці з працівником виробити цілі й завдання професійного вдосконалення та розробити план дій щодо досягнення цих цілей); стрижнева концепція коучингу: не можна застосовувати насилля, якими благими цілями воно не обгрунтовувалося б; благополуччя педагога, яке досягається плідною взаємодією з керівником щодо досягнення спільних та взаемовигідних цілей; коучинг вирішуе проблему відсутності мотивації. Основна особливість і відмінність коучингу - сприяння тому, щоб людина сама навчилася, а не повчати їі (Мармаза О., 2019).

На практиці сучасний стиль керівництва з використанням ідей коучингу має відповідати певним вимогам, провідними з яких е такі: обгрунтований розподіл повноважень і відповідальності між окремими ланками і працівниками апарату управління, у тому числі і між заступниками керівника; завчасне інформування членів колективу про потребу та критерії прийняття рішення 3 того чи іншого питання, а також всебічне залучення їх до підготовки та реалізації рішень; доручення виконання конкретних завдань працівникам з урахуванням їх здібностей, навичок та знань; уважне ставлення до пропозицій, прохань підлеглих; згуртування колективу, підкріплення існуючих між його членами ділових відносин позитивними неформальними зв'язками; створення у колективі нетерпимого ставлення до порушників дисципліни і намагань приховати недоліки у роботі, виховання у людях добросовісності та принциповості; виявлення волі та настирливості 3 метою своєчасного і якісного виконання завдань (Мармаза О., 2019).

Коучинг - це стиль управлінської поведінки, який передбачає: орієнтацію на корпоративне управління; створення команди однодумців, підтримки; визначення спільних цілей діяльності; організацію співробітництва; послаблення контролю за рахунок розвитку самостійності та відповідальності персоналу; ефективне спілкування; сприяння творчості.

На прикладі партисипативного управління та коучингу ми окреслили аксіологігний контент вибору інновацій. Щоб уникнути сліпого та бездумного впровадження інноваційних технологій, керівник закладу освіти повинен проявити здатність аналізувати та приймати виважені рішення щодо їх доцільності.

Обговорення / Discussions. Проблеми інноваційного управління закладом освіти розглядалися у дослідженнях Л. Ващенко Н. Василенко, В. Григораша, Г. Дмитренка, Л. Даниленко, Г. Єльнікової, Л. Карамушки, С. Королюк, В. Лунячека, Н. Погрібної З. Рябової та інших науковців.

У освітній галузі можливості партисипативного менеджменту цілеспрямовано вивчалися вкрай мало. $\mathrm{C}$ лише поодинокі статті та окремі тези сучасних науковців, які пов'язують партисипативний підхід до управління закладом освіти із демократизацією управління в освіті та мотивацією педагогів: О. Афанас'єва, І. Бичева, І. Блясова, Є. Казаєва, І. Кравченко, О. Нікітіна, Т. Орлова, М. Понеделкова, С. Суворова, О. Шукліна та ін. Однак, такі дослідження мають методологічні, теоретичні й методичні перспективи та практичний потенціал. Доцільно визначити сутність партисипативного управління та на цій основі розкрити особливості партисипації в управлінні педагогічними кадрами, виявити найбільш сильні та слабкі місця такого підходу в умовах закладу освіти.

Коучинг як ефективний метод керівництва розкривали В. Білуха, С. Воронова, О. Дмитрієва, М. Каразін, Л. Карамушка, Д. Ненашев, І. Петровська, Т. Посадська, С. Романова, Т. Сазонова, I. Шульженко та ін. Вивчення науково-методичної джерельної бази дозволяе встановити наявність суперечностей між: об’ективною необхідністю вдосконалення праці керівників закладів освіти через вдало обраний стиль управління та недостатньою розробкою моделей оптимальних стилів управлінської поведінки; прагненням керівників впровадити коучинг задля вдосконалення стилю управління та істотними прогалинами у його теоретичному та методичному вивченні.

Важливо з'ясувати аксіологічний контент кожної окремої управлінської інновації, що підвищить мотивацію керівників закладів освіти до їх впровадження в практику роботи.

Висновки / Conclusions. Значимість інновацій пов'язана із можливістю удосконалення діяльності керівника, персоналу, якості освітніх послуг, умов роботи, конкурентноздатності закладу тощо. Визначення цінностей управлінських інновацій через їх значимість $\epsilon$ продуктивним, оскільки дозволяе у теоретичному та практичному аспектах розглянути аксіологію 
певної інновації у площині ї̈ зв’язку з керівником, персоналом, особливостями закладу освіти.

Критерії управлінських інновацій у аксіологічному контенті - це: актуальність, що означає відповідність цілям та завданням діяльності; пріоритетність, що відображає першочерговість вирішення проблем в управлінні закладом освіти; значущість, що полягає у вирішенні проблем, які $е$ найбільш важливими для розвитку закладу освіти; багатоаспектність, що дозволяе одночасно впливати на різні системи закладу освіти.

Управлінську інновацію доцільно оцінювати з точки зору можливостей самої інновації (iї наукового потенціалу, теоретичного обтрунтування, алгоритму реалізації, перспективності та подальшого використання) та витрат і зусиль на їі впровадження (фінанси, інвестиції, матеріально-технічне забезпечення, час, кадрові можливості).

\section{Список використаних джерел і літератури:}

Аксіологія. Взято з https://uk.wikipedia.org/wiki/АксіологіяАксіоло́гія [in Ukrainian].

Василенко, Н. В. (2007). Підготовка керівників загальноосвітніх навчальних закладів до інноваційної діяльності. (Автореф. дис. ... канд пед. наук). Київ [in Ukrainian].

Закон України «Про освіту». (2017). Взято з https://osvita.ua/legislation/law/2231/ [in Ukrainian].

Концепиія реалізації державної політики у собері рефбормування загальної середньої освіти "Нова українська школа». (2016). Взято з https://mon.gov.ua/storage/app/media/zagalna\%20serednya/nova-ukrainskashkola-compressed.pdf [in Ukrainian].

Лісовий, В. С. (2001). Аксіологія. Енциклопедія сучасної України. Взято з https://esu.com.ua/search_articles.php?id=43500 [in Ukrainian].

Мармаза, О. I. (2017). Менеджмент освітньої організації. Харків: Щедра садиба [in Ukrainian].

Мармаза, О. I. (2019). Інновації в менеджменті освіти: [моногр.]. Харків: Основа [in Ukrainian].

Підлісний, М. М. (2020). Проблеми аксіологї та шляхи їх вирішення: [моногр.]. Дніпро: Видавець Біла К. O. [in Ukrainian].

Cac, Н. (2013). Основи інноваційного управління навчальними закладами. Полтава: ПНПУ імені В. Г. Короленка [in Ukrainian].

Стратегія сталого розвитку України до 2030 року. https://ips.ligazakon.net/document/JH6YF00A?an=332 [in Ukrainian].

\section{References:}

Aksiolohiia [Axiology]. Retrieved from https://uk.wikipedia.org/wiki/АксіологіяАксіоло́гія [in Ukrainian].

Vasylenko, N. V. (2007). Pidhotovka kerivnykiv zahalnoosvitnikh navchalnykh zakladiv do innovatsiinoi diialnosti [Training of Heads of Secondary Schools for Innovative Activities]. (Extended abstract of Candidate's thesis). Kyiv [in Ukrainian].

Zakon Ukrainy "Pro osvitu" [Law of Ukraine "On education»]. (2017). Retrieved from https://osvita.ua/legislation/law/2231/ [in Ukrainian].

Kontseptsiia realizatsii derzhavnoi polityky u sferi reformuvannia zahalnoi serednoi osvity "Nova ukrainska shkola" [The Concept of Implementation of State Policy in the Field of Reforming General Secondary Education "New Ukrainian School»]. Retrieved from https://mon.gov.ua/storage/app/media/zagalna\%20serednya/novaukrainska-shkola-compressed.pdf [in Ukrainian].

Lisovyi, V. S. (2001). Aksiolohiia [Axiology]. Entsyklopediia suchasnoi Ukrainy - Encyclopedia of Modern Ukraine]. https://esu.com.ua/search_articles.php?id=43500 [in Ukrainian].

Marmaza, O. I. (2019). Innovatsii v menedzhmenti osvity [Innovations in Education Management]. Kharkiv: Osnova [in Ukrainian].

Marmaza, O. I. (2017). Menedzhment osvitnoi orhanizatsii [Management of Educational Organization]. Kharkiv: Shchedra sadyba [in Ukrainian].

Pidlisnyi, M. M. (2020). Problemy aksiolohii ta shliakhy yikh vyrishennia [Problems of Axiology and Ways to Solve Them]. Dnipro: Vydavets Bila K. O. [in Ukrainian].

Sas, N. (2013). Osnovy innovatsiinoho upravlinnia navchalnymy zakladamy. [Fundamentals of Innovative Management of Educational Institutions]. Poltava: PNPU imeni V. H. Korolenka [in Ukrainian].

Stratehiia staloho rozvytku Ukrainy do 2030 roku [Strategy of Sustainable Development of Ukraine until 2030]. Retrieved from https://ips.ligazakon.net/document/JH6YF00A?an=332 [in Ukrainian].

Дата надходження статті: «12» травня 2021 р.

Стаття прийнята до друку: «08» червня 2021 р.

Мармаза Олександра - професор кафедри наукових основ управління Харківського національного педагогічного університету імені Г. С. Сковороди, кандидат педагогічних наук, професор

Marmaza Oleksandra - Professor of the Department of Scientific Fundamentals of Management of H. S. Skovoroda Kharkiv National Pedagogical University, Candidate of Pedagogical Sciences, Professor

\section{Цитуйте ию статтю як:}

Мармаза, О. (2021). Аксіологічний контент управлінських інновацій. Педагогічний дискурс, 30, 63-68. doi: 10.31475/ped.dys.2021.30.08.
Cite this article as:

Marmaza, O. (2021). Axiological content of management innovations. Pedagogical Discourse, 30, 63-68. doi: 10.31475/ped.dys.2021.30.08. 